\title{
An Empirical Study on the Relationship between Green Supplier Development and Firm Performance
}

\author{
Yongmei Xu, Qi Peng \\ School of Management, Jinan University, Guangzhou, China \\ Email: s.23@163.com,641473698@qq.com
}

How to cite this paper: Xu, Y.M. and Peng, Q. (2018) An Empirical Study on the Relationship between Green Supplier Development and Firm Performance. American Journal of Industrial and Business Management, 8, 930-945.

https://doi.org/10.4236/ajibm.2018.84064

Received: March 28, 2018

Accepted: April 25, 2018

Published: April 28, 2018

Copyright (c) 2018 by authors and Scientific Research Publishing Inc. This work is licensed under the Creative Commons Attribution International License (CC BY 4.0).

http://creativecommons.org/licenses/by/4.0/

(c) (i) Open Access

\begin{abstract}
Suppliers have important influence to the enterprise in terms of product and service cost, quality and delivery. Enterprises need to implement supplier development to improve suppliers' supply capabilities, and promote partnership with suppliers, so as to achieve the improvement of business efficiency. This paper defines green supplier development, divides them into direct green supplier development and indirect green supplier development, and puts forward the research hypothesis of the relationship between green supplier development and supplier relationship and firm performance. Then, using the method of questionnaire survey to collect data, according to the statistical analysis of the 259 questionnaires, the results show that the first, direct green supplier development has positive influence on the economic performance and environmental performance, but the influence of indirect green supplier development on the economic performance of enterprises is not significant. Second, supplier partnership plays a role in the influence of green supplier development on the economic performance and environmental performance.
\end{abstract}

\section{Keywords}

Green Supplier Development, Supplier Partnership, Firm Performance

\section{Introduction}

With the increasing competition of enterprises and the increasingly complex market environment, no supplier can have all the resources and ability to meet the requirements of the enterprise for a long time, but it will cost a lot of conversion costs to re-evaluate the selection of new suppliers. Therefore, if enterprises want to achieve the growth of core competitiveness, they have to develop sup- 
pliers, and supplier development has become a key problem of supply chain management. With the rise of the concept of sustainable development, supplier development plays an indispensable role in green supply chain management. However, the research on supplier development in the past was mainly from the economic point of view, only few studies considered environmental factors. The relationship between the supplier development and the firm performance is limited to the exploration of the relationship between the supplier development and the enterprise's economic benefit, and lacks the empirical research on the supplier development and the environmental performance.

At the same time, in practice, many firms lack of understanding on how to implement the supplier development to promote their own sustainable development and how the supplier development affects the performance, so they can't build a reasonable and perfect supplier development plan to carry out the supplier development practice.

Therefore, based on the above background, we study green supplier development, explore the relationship between green supplier development and firm performance, and make suggestions for enterprises based on the research results.

\section{Literature Review}

\subsection{Green Supplier Development}

Green supplier development is important for the diffusion of green supply chain management among organizations [1]. Bai and Sarkis extend the research scope of supplier development from the field of economic performance to the field of environmental performance and comprehensive performance, and promote the research of supplier development from the green point of view [2]. We refer to their research to define green supplier development as: "Core enterprises to enhance their own economic benefits, environmental benefits as the goal, with the participation of suppliers as a prerequisite, through a certain knowledge and information sharing, capital and equipment investment and other related activities, to help suppliers improve or improve performance levels and supply capacity to meet the corporate supply requirements of the general term".

Existing research summarizes many different green supplier development activities, including green knowledge transfer and communications, investment and resource transfer, management and organizational practices [1] [2] [3] [4] [5].

The existing research classifies supplier development according to different criteria. According to the idea of Wagner et al. [6], we divide green supplier development into direct green supplier and indirect green supplier. Direct supplier development means the sharing of information and knowledge between firms and suppliers, resource input to suppliers, and indirect supplier development, which refers to the organization and management practice of enterprises to suppliers. 


\subsection{Firm Performance Evaluation}

The international evaluation of enterprise performance is divided into two stages. The first stage in the 1880s to the 1980s, the performance evaluation system to profit, return on investment, cash flow and other financial indicators as the main criteria. The second stage began in the middle and late the 1980s. The enterprise operators began to consider how to conduct new performance evaluation, to adapt to the new competitive environment and development strategy. Enterprises start to customer satisfaction, strategic performance, learning and innovation ability and other non-financial indicators into the Enterprise performance evaluation system, so that the effect of business activities, the overall situation of enterprises and the future development trend can be reflected through the enterprise performance evaluation system [7].

With the increasing attention to environmental protection and the rise of the green economy, researchers began to consider environmental factors when evaluating the performance. The measurement of firm performance changes from the assessment of economic performance only to the comprehensive consideration of economic performance and environmental performance. Environmental performance refers to a series of environmental friendly effects achieved by green production activities undertaken by companies to reduce the negative impact on the environment, including increasing the utilization of natural resources, reducing waste pollution, and protecting the ecological environment [8]. The implementation of green supply chain management activities can not only achieve economic performance, but also affect environmental performance [9].

Existing research suggests that in the green supply chain management, the economic performance of the firm mainly includes sales, market share, profit margin and cost [10] [11], the environmental performance includes pollution and emission, consumption for hazardous/harmful/toxic materials, frequency for environmental accidents [9].

\section{Research Framework and Hypotheses Development}

Green supplier development is the important content of green supply chain management, and the green Supply chain management practice is driven by the enterprise's resources, environmental problems and related laws and regulations, which aims at protecting the environment and improving the environmental performance. Green Supplier development considering environmental factors can reduce the emission of pollutant, improve the utilization ratio of resources, increase the use rate of sustainable raw materials, perfect the environmental protection system of enterprises, and thus affect the environmental performance.

Some studies suggest that environmental-focused supplier development can improve the environmental practices [1] [2] [12]; Bommel emphasizes the importance of enterprise supervising and auditing suppliers to implement the sustainable development [13]. 
These considerations lead to the following sets of hypotheses:

H1: Green supplier development has positive influence on environmental performance

H1A: Direct green supplier development has positive influence on environmental performance

H1B: Indirect green supplier development as positive influence on environmental performance

The implementation of green supplier development, especially the direct green supplier development, needs to invest a lot of resources such as human, material, financial and technology, which brings about the increase of cost. Zhu et al. refer to the increased costs as negative economic performance [9]. Kumar and Rahman consider that the supplier development needs to spend a lot of cost to invest, train and develop the technology, which may weaken the economic performance [11].

However, according to the transaction cost theory, the implementation of green supplier development can reduce the procurement cost and shorten the order cycle, thus enhancing the competitive ability of enterprises. And the implementation of green supplier development, can reduce energy consumption and material use, reduce waste emissions and processing costs, bring cost savings, so that firms get positive economic performance. When the above positive and negative economic performance is offset, the profit obtained by the enterprise is the economic performance in this study. Some research suggested that enterprises implement supplier development to improve the financial performance and bring long-term economic benefits [14] [15]. Wagner et al. by investigating the relationship between supplier development and supplier development objectives, it is considered that the training and knowledge transfer of suppliers can effectively improve the supplier's ability, thus improving the performance of the supply chain [16].

These considerations lead to the following sets of hypotheses:

$\mathrm{H} 2$ : Green supplier development has positive influence on economic performance

H2A: Direct green supplier development has positive influence on economic performance

$\mathrm{H} 2 \mathrm{~B}$ : Indirect green supplier development has positive influence on economic performance

There are many benefits that enterprises can bring to implement green supplier development, and many researches show that the implementation of supplier development can enhance the relationship between enterprises and suppliers [17] [18] [19].

According to transaction cost theory, good supplier partnership can reduce the uncertainty in the process of transaction between enterprises and suppliers, so as to reduce transaction cost and improve firm performance. At the same time, can promote the supplier to support the green production of the enterprise, make the enterprise obtain more stable green raw material supply, thus 
bring environmental improvement. Chen and Paulraj found that the supplier relationship had a significant positive impact on financial performance of the firm [20]. Kumar and Rahman summarize the relationship between enterprises and suppliers in the sustainable supply chain. They think that the relationship between enterprises and suppliers has important influence on the economic, environmental and social sustainable development of enterprises [11].

This study focuses on the role of green supplier development on the economic performance and environmental performance, and combined with the previous analysis, the author thinks that the green supplier development affect the performance by influencing the relationship with the suppliers. Therefore, the following hypotheses are presented:

H3: Supplier relationship is a mediating role between green supplier development and economic performance

H4: Supplier relationship is a mediating role between green supplier development and environment performance

Based on the above hypotheses, we present the conceptual model of this study, as shown in Figure 1.

\section{Research Methodology}

\subsection{Survey Questionnaire and Measures}

The questionnaire consists of three parts: The first part is the description of the questionnaire, including the concept description of green supplier development and the description of the questionnaire. The second part is the basic information of the respondents, including the industry, size of the company and its own position. The third part is the measurement item of the questionnaire, including the scale of green supplier development, supplier partnership, corporate economic performance and environmental performance variables. The questionnaire scale adopted the Likert scale score method, and the seven descriptive scales from low to high were given to each question, and the respondents chose according to their own attitude.

1) Green Supplier development

Based on the study of Wagner et al. [6], we divide the GSD into DGSD and IGSD two dimensions. DGSD mainly includes the technology and information sharing of the supply, the investment behavior of human, material and financial

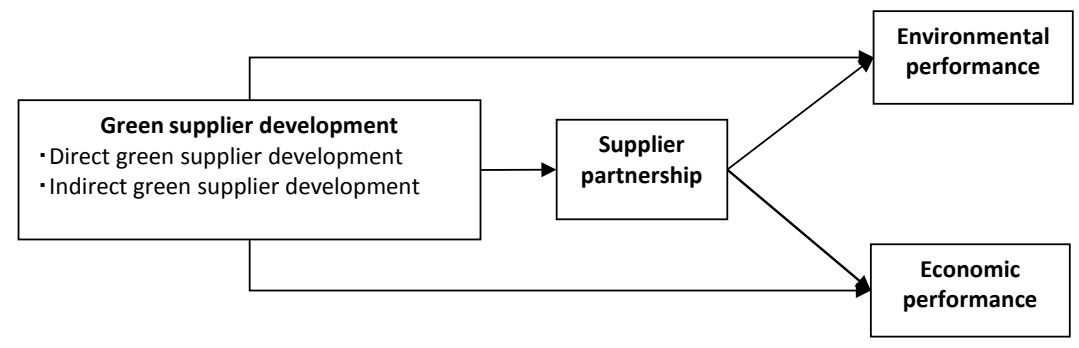

Figure 1. Conceptual model of the relationship between green supplier development and firm performance. 
resources, and IGSD includes the audit, supervision and management of the suppliers. At the same time, reference to the past research on GSD Measurement, we developed a green supplier development of the scale, as shown in Table 1 [1] [3].

2) Supplier partnership

At present, as the measurement of supplier partnership is mature, we refer to the existing scale to measure supplier partnership, as shown in Table 2 [20] [21].

3) Economic performance and environmental performance

The evaluation of economic performance has formed a relatively perfect system now. Rao and Holt in the study of green supply chain management on the impact of economic performance, the use of sales, market share, profit and product prices to measure the economic performance [10]. In addition, Kumar and Rahman in the review mentioned that many scholars in the green supply chain to assess the economic performance, the cost as a measure of economic performance indicators [11]. Therefore, this study uses four items of sales, market share, profit and cost to measure the economic performance, Table 3 is the economic performance measurement scale:

For the implementation of green supply chain management practices brought about by environmental performance, Zhu's measurement method is more mature, has been widely used by scholars. Therefore, this study uses Zhu and Sarkisscale to measure the environmental performance, Table 4 is the environmental performance measurement scale:

\subsection{Sampling and Data Collection}

This study chooses the enterprise which implements the green supplier development

Table 1. Green supplier development scale.

\begin{tabular}{|c|c|c|c|}
\hline $\begin{array}{l}\text { Independent } \\
\text { variable }\end{array}$ & Item & Item description & Source \\
\hline \multirow{6}{*}{$\begin{array}{l}\text { Direct green } \\
\text { supplier } \\
\text { development }\end{array}$} & DGSD1 & $\begin{array}{l}\text { Conduct training and education programs for supplier } \\
\text { personnel }\end{array}$ & \multirow{6}{*}{$\begin{array}{l}\text { Dou \& Zhu } \\
\text { (2014) }\end{array}$} \\
\hline & DGSD2 & Information sharing on environmental topics & \\
\hline & DGSD3 & $\begin{array}{l}\text { Giving green technological and manufacturing related } \\
\text { advice to suppliers }\end{array}$ & \\
\hline & DGSD4 & $\begin{array}{l}\text { Finance supplier major capital environmental } \\
\text { expenditures }\end{array}$ & \\
\hline & DGSD5 & $\begin{array}{l}\text { Providing environmental protection equipment and tools } \\
\text { for suppliers }\end{array}$ & \\
\hline & DGSD6 & $\begin{array}{l}\text { Transferring employees with environmental expertise to } \\
\text { suppliers }\end{array}$ & \\
\hline \multirow{4}{*}{$\begin{array}{l}\text { Indirect green } \\
\text { supplier } \\
\text { development }\end{array}$} & IGSD1 & Setting environmental improvement targets for suppliers & \multirow{4}{*}{$\begin{array}{c}\text { Bai \& Sarkis } \\
\text { (2010); } \\
\text { Fu \& Zhu } \\
\text { (2012) }\end{array}$} \\
\hline & IGSD2 & Conduct environmental audits on suppliers & \\
\hline & IGSD3 & Requiring ISO 14,000 certification for suppliers & \\
\hline & IGSD4 & $\begin{array}{l}\text { Introduce a cross-functional supply chain team with } \\
\text { environmental presence }\end{array}$ & \\
\hline
\end{tabular}


Table 2. Supplier partnership scale.

\begin{tabular}{lcll}
\hline $\begin{array}{c}\text { Mediating } \\
\text { variables }\end{array}$ & Item & \multicolumn{1}{c}{ Item description } & \multicolumn{1}{c}{ Source } \\
\hline SP1 & $\begin{array}{l}\text { We feel that we can trust our key suppliers com- } \\
\text { pletely }\end{array}$ & Fynes \& Voss (2002) \\
& SP2 & $\begin{array}{l}\text { Our key suppliers will not sacrifice your interest to } \\
\text { profit }\end{array}$ & Fynes \& Voss (2002) \\
Supplier & SP3 & $\begin{array}{l}\text { The relationship we have with key suppliers is } \\
\text { essentially evergreen }\end{array}$ & Chen \& Paulraj (2004) \\
partnership & SP4 & $\begin{array}{l}\text { We expect our relationship with key suppliers to last } \\
\text { a long time }\end{array}$ & Fynes \& Voss (2002) \\
& Chen \& Paulraj (2004) & $\begin{array}{l}\text { The relationship that we have with key suppliers is } \\
\text { something we are very committed to }\end{array}$ & $\begin{array}{c}\text { Fynes \& Voss (2002) } \\
\text { Chen \& Paulraj (2004) }\end{array}$ \\
& SP6 & $\begin{array}{l}\text { The relationship that our firm has with key } \\
\text { suppliers deserves our maximum effort to maintain }\end{array}$ & Fynes \& Voss (2002) \\
\hline
\end{tabular}

Table 3. Economic performance scale.

\begin{tabular}{cccc}
\hline $\begin{array}{c}\text { Dependent } \\
\text { variable }\end{array}$ & Item & Item description & Source \\
\hline & ECP1 & Sales expansion & Rao \& Holt (2005) \\
$\begin{array}{c}\text { Economic } \\
\text { Performance }\end{array}$ & ECP2 & Market share expansion & Rao \& Holt (2005) \\
& ECP3 & Increased profit margin & Rao \& Holt (2005) \\
& & Cost reduction in long term & Kumar \& Rahman (2015) \\
\hline
\end{tabular}

Table 4. Environmental performance scale.

\begin{tabular}{|c|c|c|c|}
\hline $\begin{array}{l}\text { Dependent } \\
\text { variable }\end{array}$ & Item & Item description & Source \\
\hline \multirow{4}{*}{$\begin{array}{l}\text { Environmental } \\
\text { Performance }\end{array}$} & EVP1 & Reduction of pollution and emission & \multirow{4}{*}{ Zhu \& Sarkis (2004) } \\
\hline & EVP2 & $\begin{array}{c}\text { Decrease of consumption for } \\
\text { hazardous/harmful/toxic materials }\end{array}$ & \\
\hline & EVP3 & $\begin{array}{l}\text { Decrease of frequency for environmental } \\
\text { accidents }\end{array}$ & \\
\hline & EVP4 & Improve the firm's environmental situation & \\
\hline
\end{tabular}

as the sample. The questionnaire was distributed through paper questionnaire and online survey. Questionnaire survey adopts the method of classification sampling, and conducts research on employees and managers of different industries. At the same time, the method of random sampling was adopted, and the social network was used for the distribution according to the availability. A total of 290 questionnaires were issued and 259 valid questionnaires were collected, with an effective rate of $89.3 \%$.

The descriptive statistical analysis results of the main sample of the respondents are shown in Table 5.

As shown in Table 5, the companies surveyed in this study are distributed in 
Table 5. Selected characteristics of the sample.

\begin{tabular}{|c|c|c|}
\hline Characteristic & Frequency & Percent of sample \\
\hline \multicolumn{3}{|l|}{ Number of employees } \\
\hline$<100$ & 91 & 35.1 \\
\hline $101-500$ & 96 & 37.1 \\
\hline $501-1000$ & 42 & 16.2 \\
\hline$>1000$ & 30 & 11.6 \\
\hline \multicolumn{3}{|l|}{ Industry } \\
\hline Manufacturing & 66 & 25.5 \\
\hline Communications/Telecommunications & 28 & 10.8 \\
\hline Logistics/Transportation & 22 & 8.5 \\
\hline Machinery/Equipment & 17 & 6.6 \\
\hline Apparel/Textile/Leather & 19 & 7.3 \\
\hline Health/Medical & 23 & 8.9 \\
\hline Computer/Software & 31 & 12.0 \\
\hline Entertainment/Life Services & 19 & 7.3 \\
\hline Other & 34 & 13.1 \\
\hline \multicolumn{3}{|l|}{ Department } \\
\hline Purchasing Department & 88 & 34.0 \\
\hline Marketing Department & 26 & 10.0 \\
\hline Finance Department & 49 & 18.9 \\
\hline Middle and senior management & 56 & 21.6 \\
\hline Other & 40 & 15.4 \\
\hline
\end{tabular}

industries such as manufacturing, IT, healthcare, and communications. Manufacturing companies account for more than one quarter of the total sample size. Manufacturing companies to implement supplier development activities, and establish a good partnership with suppliers, can bring greater benefits for the company, so supplier development activities are particularly important for manufacturing companies. The companies surveyed were mainly SMEs, of which $72.2 \%$ were small companies with fewer than 500 employees and only $11.6 \%$ were large enterprises with more than 1000 employees, so the degree of sample variation is small. The respondents were generally middle and senior managers of the company and employees of the purchasing department, marketing department, or finance department. They were relatively familiar with the supplier's situation and performance level of the company and ensured the effectiveness of the investigation.

\section{Data Analysis}

\subsection{Reliability and Validity}

1) Reliability. We use Cronbach's coefficient alpha to measure the scale relia- 
bility. As shown in Table 6, the coefficients of Cronbach's alpha of the instruments are all higher than 0.7 (ranging from 0.826 to 0.886 ). This indicates that the reliability of the scale is acceptable [22].

2) Validity. All of the measurement items are either adapted from previous research or developed specifically for this study. Their content validity has been reviewed by experts in the purchasing field. We conduct structural validity analysis to test whether each set of items is a valid indicator of the construct. The results are shown in Table 6. As shown in Table 6, the factor load for each item is higher than 0.5 and all the items in each scale load on a single factor. These results suggest that each factor is valid as a construct [22].

Table 6. Factor loadings and Cronbach's a.

\begin{tabular}{|c|c|c|}
\hline Construct & Factor loadings & Reliability Cronbach's a \\
\hline Direct green supplier development (DGSD) & & 0.869 \\
\hline DGSD1 & 0.784 & \\
\hline DGSD2 & 0.765 & \\
\hline DGSD3 & 0.829 & \\
\hline DGSD4 & 0.861 & \\
\hline DGSD5 & 0.898 & \\
\hline DGSD6 & 0.893 & \\
\hline Indirect green supplier development (IGSD) & & 0.826 \\
\hline IGSD1 & 0.819 & \\
\hline IGSD2 & 0.837 & \\
\hline IGSD3 & 0.751 & \\
\hline IGSD4 & 0.726 & \\
\hline Supplier partnership (SP) & & 0.881 \\
\hline SP1 & 0.808 & \\
\hline SP2 & 0.706 & \\
\hline SP3 & 0.812 & \\
\hline SP4 & 0.788 & \\
\hline SP5 & 0.800 & \\
\hline SP6 & 0.847 & \\
\hline Environmental performance $(E V P)$ & & 0.886 \\
\hline EVP1 & 0.868 & \\
\hline EVP2 & 0.845 & \\
\hline EVP3 & 0.871 & \\
\hline EVP4 & 0.875 & \\
\hline Economic performance $(E C P)$ & & 0.847 \\
\hline ECP1 & 0.828 & \\
\hline ECP2 & 0.836 & \\
\hline ECP3 & 0.870 & \\
\hline ECP4 & 0.780 & \\
\hline
\end{tabular}




\subsection{Correlation Analyses between Variables}

The Spearman rank correlation is often used to describe the relationship between two variables. Therefore, we conduct a series of Spearman bivariate correlation analyses to identify the relationships between the independent variables and the dependent variables. The results are shown in Table 7. The coefficients of the correlation are all significant at the 0.05 level, indicating that all the green supplier development variables are significantly related to firm performance.

\subsection{Regression Analysis}

We examine $\mathrm{H} 1$ and $\mathrm{H} 2$ by simple linear regression and use multiple linear regression to test $\mathrm{H} 1 \mathrm{a}, \mathrm{H} 1 \mathrm{~B}$ and $\mathrm{H} 2 \mathrm{~A}, \mathrm{H} 2 \mathrm{~B}$.

Before conducting regression analysis, we first test the multivariate collinearity between variables. The Variance Inflation Factor (VIF) is a commonly used measure of multivariate collinearity between variables. When VIF is less than 5 , there is no multivariate collinearity problem between variables [23]. As shown in Table 8, all the VIFs are within the VIF limit of 5, indicating that multicollinearity does not have an influence on the least squares estimates. Thus, we retain all the variables in the model for further analysis.

First, we use regression analysis to examine the relationship between green supplier development and environmental performance. $\mathrm{H} 1$ proposes that green supplier development enhances the firm's environment performance effectively. It was tested by regression analysis and the test results were shown in Table 8.

Table 7. Spearman correlation matrix between variables.

\begin{tabular}{|c|c|c|c|c|c|c|c|c|}
\hline & Mean & $\begin{array}{l}\text { Standard } \\
\text { deviation }\end{array}$ & 1 & 2 & 3 & 4 & 5 & 6 \\
\hline 1. DGSD & 4.856 & 0.876 & 1 & & & & & \\
\hline 2. IGSD & 4.997 & 0.924 & $0.644^{* *}$ & 1 & & & & \\
\hline 2. GSD & 4.926 & 0.840 & $0.930^{* *}$ & $0.937^{\star *}$ & 1 & & & \\
\hline 4. SP & 5.262 & 0.792 & $0.568^{\star *}$ & $0.508^{\star *}$ & $0.575^{\star *}$ & 1 & & \\
\hline 5. $E V P$ & 5.173 & 0.874 & $0.578^{\star *}$ & $0.532^{\star *}$ & $0.593^{\star *}$ & $0.694^{* *}$ & 1 & \\
\hline 6. $E C P$ & 5.114 & 0.833 & $0.597^{\star *}$ & $0.543^{\star *}$ & $0.610^{* *}$ & $0.687^{\star *}$ & $0.650^{* *}$ & 1 \\
\hline
\end{tabular}

Table 8. Summary of regression analysis.

\begin{tabular}{|c|c|c|c|c|c|c|c|c|c|}
\hline $\begin{array}{c}\text { Dependent } \\
\text { variable }\end{array}$ & $\begin{array}{l}\text { ndependent } \\
\text { variable }\end{array}$ & $\mathrm{R}^{2}$ & F & Sig. & VIF & Beta & $t$ & Sig. & Hypothesis \\
\hline \multirow[t]{3}{*}{ EVP } & GSD & 0.352 & 139.619 & 0.000 & 1.00 & 0.617 & 11.816 & 0.000 & H1 \\
\hline & DGSD & \multirow{2}{*}{0.357} & \multirow{2}{*}{71.074} & \multirow{2}{*}{0.000} & 2.237 & 0.408 & 5.447 & 0.000 & $\mathrm{H} 1 \mathrm{a}$ \\
\hline & IGSD & & & & 2.237 & 0.216 & 3.040 & 0.003 & $\mathrm{H} 1 \mathrm{~b}$ \\
\hline \multirow[t]{3}{*}{ ECP } & GSD & 0.372 & 152.213 & 0.000 & 1.00 & 0.605 & 12.337 & 0.000 & $\mathrm{H} 2$ \\
\hline & DGSD & \multirow{2}{*}{0.379} & \multirow{2}{*}{78.027} & \multirow{2}{*}{0.000} & 2.237 & 0.412 & 5.876 & 0.000 & $\mathrm{H} 2 \mathrm{a}$ \\
\hline & IGSD & & & & 2.237 & 0.120 & 1.933 & 0.053 & $\mathrm{H} 2 \mathrm{~b}$ \\
\hline
\end{tabular}


As shown in Table 8, the standardized coefficient (Beta) is 0.617 , and the result is significant at 0.05 level. This provides an empirical evidence for the enabling effect of green supplier development on environment performance, and $\mathrm{H} 1$ is established. Then, we test $\mathrm{H} 1 \mathrm{a}$ and $\mathrm{H} 1 \mathrm{~b}$, the result suggests that these two hypotheses are supported as shown by the standardized coefficient (Beta) of 0.408 and 0.216 in Table 8, the result are significant at 0.05 level. Thus, $\mathrm{H} 1 \mathrm{a}$ and $\mathrm{H} 1 \mathrm{~b}$ are supported. Both direct green supplier development and indirect green supplier development have significant positive effects on environmental performance.

Next, we examine the relationship between green supplier development and economic performance. $\mathrm{H} 2$ proposes that green supplier development enhances the economic performance effectively. As shown in Table 8, the standardized coefficient (Beta) is 0.605 , and the result is significant at 0.05 level. This provides an empirical evidence for the enabling effect of green supplier development on economic performance, and $\mathrm{H} 2$ is established. Then, we test $\mathrm{H} 2 \mathrm{a}$ and $\mathrm{H} 2 \mathrm{~b}$, the result suggests that $\mathrm{H} 2 \mathrm{a}$ is supported as shown by the standardized coefficient (Beta) of 0.412 in Table 8 and the result are significant at 0.05 level. While H2b is not supported, which means that indirect green supplier development have no significant effect on economic performance.

The hierarchical regression analysis is used to assess $\mathrm{H} 3$ and $\mathrm{H} 4$ in this study.

Hierarchical regression analysis method to test the intermediary role of supplier partnership requires two steps. In the first step, the explanatory variable is green supplier development, and the result variable is economic performance and environment performance. The second step is to add a second explanation variable supplier partnership based on the first step, and the analysis results are shown in Table 9.

As shown in Table 9, in the first step, the regression coefficient of green supplier development to economic performance is 0.605 . The significance level is less than 0.005 , indicating that supplier development activities have a significant impact on economic performance, explanatory variables to economic performance interpretation rate of $37 \%$. In the second step, after joining supplier Partnership, the explanatory rate of two explanatory variables to economic performance reached $53.7 \%$, and two regression coefficients reached significant level. This shows that the supplier partnership plays a partial mediating role in the

Table 9. Result of hierarchical regression analysis.

\begin{tabular}{ccccc}
\hline & \multicolumn{2}{c}{ Economic performance } & \multicolumn{2}{c}{ Environment performance } \\
\hline & Step1 & Step2 & Step1 & Step2 \\
Green supplier development & $0.605^{* *}$ & $0.617^{* *}$ & $0.302^{* *}$ & $0.319^{* *}$ \\
Supplier partnership & & & $0.581^{* *}$ & $0.529^{* *}$ \\
$\Delta \mathrm{R}^{2}$ & 0.370 & 0.350 & 0.534 & 0.537 \\
$\mathrm{~F}$ & 152.213 & 139.619 & 148.859 & 150.791 \\
\hline
\end{tabular}

${ }^{\star} p<0.05,{ }^{* *} p<0.01$. 
relationship between green supplier development and economic performance, and $\mathrm{H} 3$ is established. At the same time, in the first step, the regression coefficient of green supplier development to environmental performance is 0.617 ; the significance level is less than 0.05 , which indicates that the supplier development activity has a significant impact on environmental performance, explaining the variable's interpretation rate to environmental performance is $35 \%$. In the second step, the explanatory rate of two explanatory variables to the total environmental performance variance was $53.4 \%$, and the two regression coefficients reached a significant level after the supplier partnership was added. This shows that the supplier partnership plays a partial mediating role in the relationship between green supplier development and environment performance, and $\mathrm{H} 4$ is established.

\section{Discussion}

\subsection{The Influence of Green Supplier Development Activities on Firm Performance}

According to the previous analysis, the implementation of green supplier development can significantly promote the improvement of firm environmental performance, H1 was established. Green supplier development, considering environmental factors, can improve the environment of suppliers to obtain more environmental protection and clean raw materials, reduce pollutant emission, improve resource utilization rate and increase sustainable raw material usage, and finally get the improvement of environmental performance. At the same time, direct green supplier development and indirect green supplier development have significant effects on environmental performance, H1a and H1b are established. Direct green supplier development through the supplier training, environmental protection information and knowledge exchange, environmental investment activities, the supplier's environmental improvement, thereby reducing the use of toxic substances, to produce more environmentally friendly products. The indirect green supplier development can improve the environmental performance of the supplier by means of monitoring and auditing the suppliers.

$\mathrm{H} 2$ is established, the green Supplier development has a significant effect on the economic performance. At the same time, H2a is also established. Direct supplier development can bring significant positive impact on the economic performance. However, $\mathrm{H} 2 \mathrm{~b}$ has not been supported, indicating that the indirect supplier development have no significant impact on the economic performance. Enterprises to implement indirect green supplier development, monitoring and auditing of suppliers will cost a certain amount of money and have little influence on the economic performance. First, the possible reason is that direct green supplier development through the investment of suppliers, can quickly improve the supplier's supply capacity in a short time, thus affecting the economic efficiency of enterprises, but the indirect green supplier development for the improvement of firm economic performance is a long-term accumulation process, 
may be difficult to manifest in a shorter period of time. Secondly, the sample of this survey selected enterprises to implement green supplier development of different time, there may be some enterprises are still in the early stage of green supplier development, for indirect green supplier development have not been able to translate into economic benefits.

\subsection{The Mediating Effect of Supplier Partnership}

H3 is supported. Supplier partnerships play a part in mediating the impact of green supplier development on the economic performance of enterprises, through the implementation of green supplier development to enhance the partnership with suppliers to enhance economic efficiency. Implementing green Supplier development is beneficial to establish long-term and stable supplier partnership with suppliers, good supplier partnership can play a key role in reducing uncertainty in transaction process, and can significantly reduce cost, shorten order time, increase productivity and product quality, and thus enhance the competitive advantage of enterprises, and bring economic performance improvement.

H4 is also validated, it shows that the green supplier development not only directly affect the environmental performance, but also indirectly affect the firm environmental performance by improving the supplier partnership. Enterprises and suppliers to establish long-term and stable partnership, to enable suppliers to more support the green production of enterprises, to ensure the stability and reliability of green raw materials supply, enterprises to produce greener green products, resulting in environmental improvement.

\section{Conclusion}

This study discusses the impact of green supplier development on firm economic performance and environmental performance, and studies the mediating role of supplier partnership in the relationship between green supplier development and firm performance. Firstly, we review the research status of green supplier development, supplier partnership and firm performance, and then put forward the conceptual model and research hypothesis, and test the hypothesis by questionnaire and data analysis. Finally, the following two research conclusions are obtained: Not surprisingly, we find that green supplier development can significantly improve the environmental performance and economic performance. Interestingly, the direct green supplier development can significantly improve the economic performance and environmental performance, but the indirect green supplier development can significantly improve the environmental performance of enterprises, while the firm's economic performance has no significant impact. Moreover, supplier partnership plays a part mediating role in the relationship between green supplier development and enterprise economic performance, and it also plays a part mediating role in the relationship between green supplier development and environmental performance. 


\subsection{Theoretical Contributions}

Green supplier development is an important part of green supplier management. This study defines and classifies green supplier development, which is divided into direct green supplier development and indirect green supplier development. It is conducive to further research on the development of green suppliers. From the perspective of transaction cost theory, this study studies the relationship between green supplier development and firm performance and finds that supplier partnership plays an intermediary role in the impact of green supplier development on firm performance. It further clarified the mechanism of the role of green supplier development on firm performance. At the same time, the results of this study show that different types of green supplier development activities affect economic performance and environmental performance respectively, filling the gap of existing research.

\subsection{Managerial Implications}

We investigated and analyzed the green supplier development of Chinese enterprises, the results of which can provide enlightenment to enterprise practice.

First of all, the implementation of green supplier development can bring about the improvement of firm environmental performance and economic performance. The practice of Toyota, BASF and other enterprises also shows that the implementation of green Supplier development activities can enable enterprises to gain greater competitive advantage. Therefore, enterprises should attach importance to the impact of green supplier development on their performance, and continuously strengthen the practice of green supplier development.

Secondly, the Green supplier development practice in our country is in the initial stage. Many enterprises only stay in the supplier training, exchange, investment and other direct green supplier development, for the implementation of indirect green supplier development awareness that is not enough, the implementation of the way and the strength of the existence of a certain shortage. However, the indirect green supplier development can also improve the supplier's environmental supply ability, thus bringing the improvement of environmental performance. Therefore, in the practice of green supplier development, enterprises should focus on the combination of direct green supplier development and indirect green supplier development, and establish a perfect green supplier development practice system.

Finally, good supplier partnership is an important factor to improve the performance of enterprises. In the process of implementing green supplier development, we should strengthen communication with suppliers and establish long-term strategic supplier partnership.

\subsection{Limitations and Future Research Directions}

We explored the implementation of green supplier development in different industries in China, and did not carry out research on a particular industry, which 
may lead to insufficient industry pertinence. Future research can select a specific industry as the research object. The results of the research will be the implementation of green supplier development has more industry-specific guidance.

This study is a cross-sectional study. The data collected is only a point of time, not time series data, which may affect the research conclusions. In the future research, we can consider the long time tracking of the same survey, and dynamic research on the different influence of green supplier development in the front, middle and later stages.

Also, there are studies on supplier development activities that consider economic, environmental, and social factors at present. However, there is no empirical study on the effect of supplier development activities on the triple performance of companies. Therefore, in the future, we can study how companies implement supplier development activities and how they will affect their economic performance, environmental performance, and social performance.

\section{References}

[1] Fu, X., Zhu, Q. and Sarkis, J. (2012) Evaluating Green Supplier Development Programs at a Telecommunications Systems Provider. International Journal of Production Economics, 140, 357-367. https://doi.org/10.1016/j.ijpe.2011.08.030

[2] Bai, C. and Sarkis, J. (2010) Green Supplier Development: Analytical Evaluation Using Rough Set Theory. Journal of Cleaner Production, 18, 1200-1210. https://doi.org/10.1016/j.jclepro.2010.01.016

[3] Dou, Y., Zhu, Q. and Sarkis, J. (2014) Evaluating Green Supplier Development Programs with a Grey-Analytical Network Process-based Methodology. European Journal of Operational Research, 233, 420-431. https://doi.org/10.1016/j.ejor.2013.03.004

[4] Akman, G. (2015) Evaluating Suppliers to Include Green Supplier Development Programs via Fuzzy C-Means and VIKOR Methods. Computers \& Industrial Engineering, 86, 69-82. https://doi.org/10.1016/j.cie.2014.10.013

[5] Bai, C. and Sarkis, J. (2011) Evaluating Supplier Development Programs with a Grey Based Rough Set Methodology. Expert Systems with Applications, 38, 13505-13517. https://doi.org/10.1016/j.eswa.2011.02.137

[6] Wagner, S.M. (2010) Indirect and Direct Supplier Development: Performance Implications of Individual and Combined Effects. IEEE Transactions on Engineering Management, 57, 536-546. https://doi.org/10.1109/TEM.2009.2013839

[7] Sun, Y.F. and Li, Y. (2004) A Theoretical Review and Analysis of Existing Problems in Firm Performance Evaluation. Prediction, 23, 41-47.

[8] Paulraj, A. and Williamson, S. (2011) Internal and External Environmental Practices within the Paper Industry: Antecedents and Effect on Financial Performance. International Academy of Business and Economics, 11, No. 2.

[9] Zhu, Q. and Sarkis, J. (2004) Relationships between Operational Practices and Performance among Early Adopters of Green Supply Chain Management Practices in Chinese Manufacturing Enterprises. Journal of Operations Management, 22, 265-289. https://doi.org/10.1016/j.jom.2004.01.005

[10] Rao, P. and Holt, D. (2005) Do Green Supply Chains Lead to Competitiveness and Economic Performance? International Journal of Operations \& Production Man- 
agement, 25, 898-916. https://doi.org/10.1108/01443570510613956

[11] Kumar, D. and Rahman, Z. (2015) Sustainability Adoption through Buyer Supplier Relationship across Supply Chain: A Literature Review and Conceptual Framework. International Strategic Management Review, 3, 110-127. https://doi.org/10.1016/j.ism.2015.04.002

[12] Ciliberti, F., Pontrandolfo, P. and Scozzi, B. (2008) Logistics Social Responsibility: Standard Adoption and Practices in Italian Companies. International Journal of Production Economics, 113, 88-106. https://doi.org/10.1016/j.ijpe.2007.02.049

[13] Bommel, H.W.M.V. (2011) A Conceptual Framework for Analyzing Sustainability strategies in Industrial Supply Networks from an Innovation Perspective. Journal of Cleaner Production, 19, 895-904. https://doi.org/10.1016/j.jclepro.2010.12.015

[14] Krause, D.R., Handfield, R.B. and Scannell, T.V. (1998) An Empirical Investigation of Supplier Development: Reactive and Strategic Processes. Journal of Operations Management, 17, 39-58. https://doi.org/10.1016/S0272-6963(98)00030-8

[15] Carr, A.S. and Kaynak, H. (2007) Communication Methods, Information Sharing, Supplier Development and Performance: An Empirical Study of Their Relationships. International Journal of Operations \& Production Management, 27, 346-370. https://doi.org/10.1108/01443570710736958

[16] Wagner, S.M. and Krause, D.R. (2009) Supplier Development: Communication Approaches, Activities and Goals. International Journal of Production Research, 47, 3161-3177. https://doi.org/10.1080/00207540701740074

[17] Wagner, S.M. (2011) Supplier Development and the Relationship Life-Cycle. International Journal of Production Economics, 129, 277-283. https://doi.org/10.1016/j.ijpe.2010.10.020

[18] Simpson, D.F. and Power, D.J. (2005) Use the Supply Relationship to Develop Lean and Green Suppliers. Supply Chain Management, 10, 60-68. https://doi.org/10.1108/13598540510578388

[19] Yang, F., Xiong, F. and Zhang, X.F. (2017) The Impact of Sustainable Supplier Management Practices on Buyer-Supplier Performance: An Empirical Study in China. Review of International Business and Strategy, 27, 112-132. https://doi.org/10.1108/RIBS-08-2016-0043

[20] Chen, I.J. and Paulraj, A. (2004) Towards a Theory of Supply Chain Management: The Constructs and Measurements. Journal of Operations Management, 22, 119-150. https://doi.org/10.1016/j.jom.2003.12.007

[21] Voss, C. and Fynes, B. (2002) The Moderating Effect of Buyer-Supplier Relationships on Quality Practices and Performance. International Journal of Operations \& Production Management, 22, 589-613. https://doi.org/10.1108/01443570210427640

[22] Nunally, J.C. (1978) Psychometric Theory. 2nd Edition, McGraw-Hill, New York.

[23] Malhotra, N.K. (1999) Marketing Research: An Applied Orientation. Australasian Marketing Journal, 10, 72-74. 